\title{
In Silico Characterization of $\beta$-Defensin-1 Complementary Deoxyribonucleic Acid from Osmanabadi Goat
}

\author{
Vipul $^{1}$, Abhijit K Barate ${ }^{2^{*}}$ and Tejas C Shende ${ }^{1}$ \\ ${ }^{1}$ Department of Animal Genetics, KNPCVS, Shirwal, Maharashtra, INDIA \\ ${ }^{2}$ Department of Vet. Biochemistry, KNPCVS, Shirwal, Maharashtra, INDIA
}

"Corresponding author: AK Barate; E-mail:abhijit.barate@gmail.com

Received: 21 Dec., 2020

Revised: 18 Jan., 2021

Accepted: 24 Jan., 2021

\begin{abstract}
Beta-defensins are cationic antimicrobial peptides (AMPs) involved in resistance against microbial colonization. In this study total RNA was extracted from tongue of Osmanabadi goats and used to synthesize $\beta$-Defensin- 1 complementary deoxyribonucleic Acid (cDNA) using reverse transcriptase. In this study in silico characterization of Osmanabadi goat $\beta$-Defensin- 1 cDNA and its deduced peptide was carried out using PCR, Sequencing and DNAstar programme. CDS of Osmanabadi goat $\beta$-Defensin- 1 consists of 195 nucleotides encoding a protein of 64 amino acids. Multiple alignment at nucleotide level revealed that Osmanabadi goat $\beta$-Defensin-1 had high homology with goat bD1-Y17679, Assam Hill goat Defensin, goat XM_018042143, and goat bD2-AJ009877 sequence. Similarly, multiple alignment at the amino acid level revealed that Osmanabadi goat $\beta$-Defensin-1 had high identity with goat bD1- O97946, Assam Hill goat-AST23025, goat- XP_017897632 and goat bD2097942 peptides. Phylogenetic tree analysis revealed that $\beta$-Defensin-1 of Osmanabadi goat, both at nucleotide and amino acid level, is closely related to goat, sheep and Reindeer sequences. The Osmanabadi goat $\beta$-Defensin- 1 cDNA sequence is identical to goat $\beta$-Defensin-1 reported from USA. No nucleotide substitution/ change was observed in Osmanabadi goat $\beta$-Defensin-1 compared to $\beta$-Defensin-1 of goat from USA. It also showed high percentage of identity with goat defensin-1 related molecules. Structure prediction using Phyre2 revealed goat $\beta$-Defensin-1 had structural similarity with bovine neutrophil beta-defensin 12 .
\end{abstract}

\section{HIGHLIGHTS}

(0 Beta-defensins are cationic antimicrobial peptides (AMPs) involved in resistance against microbial colonization.

- In silico characterization of Osmanabadi goat $\beta$-Defensin-1 cDNA

Keywords: Goat, $\beta$-defensin-1, cDNA, CDS

Domesticated animals produce a large variety of antimicrobial peptides (AMPs) that serve as natural innate barriers against gram-positive and gram-negative bacteria, viruses, fungi, and some protozoa (Brogden et al., 2003; Maia et al., 2019). The antibacterial action of most AMPs is due to their ability to change bacterial membrane structure and permeability (Zharkova et al., 2019). This leads to leakage of internal components of bacteria cell. Remaining AMPs interfere with metabolic processes (Zharkova et al., 2019). Beta-defensins are cationic AMPs found in bovidsthat are involved in resistance against microbial colonization at epithelial surfaces. Among epithelial surfaces involved in innate immunity, tongue has special importance owing to its high resistance to infection despite its frequent exposure to trauma. Osmanabadi goat is an important goat breed from Maharashtra. This goat breed is known to have high disease power against diseases (Panda, et al., 2016). There is no information available on $\beta$-defensin 1 from Osmanabadi goat. Thus, this study was designed to characterize the $\beta$-defensin 1 cDNA from

How to cite this article: Vipul, Barate, A.K. and Shende, T.C. (2021). In silico characterization of $\beta$-defensin- 1 complementary deoxyribonucleic acid from Osmanabadi goat. J. Anim. Res., 11(1): 127-130. Source of Support: None; Conflict of Interest: None क क 
Osmanabadi goat tongue tissue and perform the in silico analysis of the coding region (CDS) and deduced peptide.

In the present study, goat tongue was collected from a local abattoir on ice using aseptic conditions. The epithelial layer was scrapped and used for isolation of Total RNA with RNAiso Plus reagent (Takara, India). First strand of cDNA was synthesized using PrimeScript 1 st strand cDNA Synthesis Kit (Takara, India). $\beta$-Defensin-1 PCR was conducted using tongue cDNA as a template and specific primer set (Forward Primer 5' GAGCTCGTGACGCCAAC 3' and Reverse Primer 5' GCGATCTGTCTAAGGGCG 3') designed based on the Capra hircus mRNA for b-defensin-1 (Accession No. Y 17679). PCR was carried out as $50 \mu 1$ reaction consisting of nuclease free water $38 \mu \mathrm{l}, 10 \mathrm{x}$ buffer $5 \mu \mathrm{l}, \mathrm{MgCl} 2$ $2.5 \mu \mathrm{l}$, dNTPs mix $1 \mu \mathrm{l}$, Forward primer $0.5 \mu \mathrm{l}$, Reverse primer $0.5 \mu \mathrm{l}$, Taq DNA polymerase $0.5 \mu \mathrm{l}$ (Invitrogen, India), Template (cDNA) $2 \mu \mathrm{l}$. The thermal cycling programme was set as: Initial PCR activation at $94^{\circ} \mathrm{C}$ for 3 min, Denaturation at $94^{\circ} \mathrm{C}$ for $40 \mathrm{sec}$., Annealing at $54^{\circ} \mathrm{C}$ for $1 \mathrm{~min}$, Elongation at $72^{\circ} \mathrm{C}$ for $1 \mathrm{~min}$, for 30 cycles and Final Extension at $72^{\circ} \mathrm{C}$ for $10 \mathrm{~min}$. The PCR products were purified, quantified and submitted to geneOmbio technologies Pvt Ltd, India for sequencing. Sequence analysis was done by comparing $\beta$-defensin 1 amplicon sequence with published sequences available at National Center for Biotechnology Information (NCBI, USA) using DNAstar software (USA).Structure prediction and analysis of the deduced peptide was carried out using Phyre2 (Kelley et al., 2015).

The 275bpPCR product of $\beta$-Defensin-1 is shown in Fig. 1. ORF of Osmanabadi goat $\beta$-Defensin- 1 consists of 195 nucleotides and encodes a peptide of 64 amino acids. This results are in agreement with the previous report by Zhao et al (1999). Multiple alignment at nucleotide level revealed that Osmanabadi goat $\beta$-Defensin-1 had 100\%, 99.5\%, $99.5 \%$ and $95.4 \%$ homology with goat bD1-Y17679, Assam Hill goat Defensin, goat XM_018042143, and goat bD2-AJ009877 nucleotide sequence respectively (Fig. 2a). Furthermore multiple alignment at the amino acid level revealed that Osmanabadi goat $\beta$-Defensin-1 had 100\%, 98.4, 98.4 and 87.5 identity with goat bD1- O97946, Assam Hill goat-AST23025, goat- XP_017897632 and goat bD2097942 peptides respectively (Fig 2b). Osmanabadi goat $\beta$-Defensin-1 showed9 nucleotide $(26 \mathrm{~T}>\mathrm{C}, 77 \mathrm{G}>\mathrm{A}, 80$ $\mathrm{G}>\mathrm{A}, 83 \mathrm{G}>\mathrm{A}, 94 \mathrm{C}>\mathrm{T}, 119 \mathrm{~T}-\mathrm{C}, 121 \mathrm{~A}>\mathrm{G}, 160 \mathrm{~T}>\mathrm{C}$ and
$161 \mathrm{~T}>\mathrm{A})$ and 8 amino acid $(9 \mathrm{~V}>\mathrm{A}, 26 \mathrm{R}>\mathrm{I}, 27 \mathrm{~S}>\mathrm{N}, 28$ $\mathrm{R}>\mathrm{H}, 32 \mathrm{H}>\mathrm{Y}, 40 \mathrm{~L}>\mathrm{P}, 41 \mathrm{~T}>\mathrm{A}$ and $54 \mathrm{~F}>\mathrm{H}$ ) substitutions compared to goat bD2.

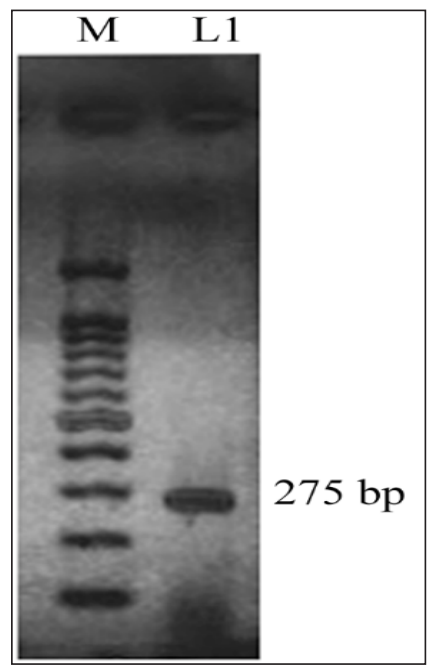

Fig. 1: $\beta$-Defensin-1 amplification: M- DNA ladder, L1- Goat $\beta$-Defensin-1 amplicon

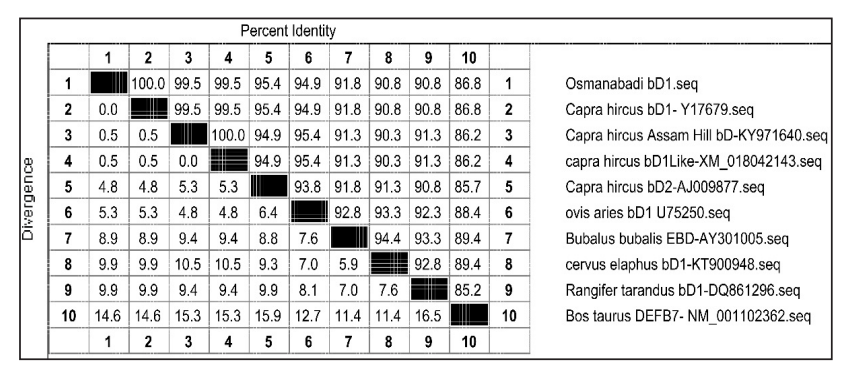

(a)

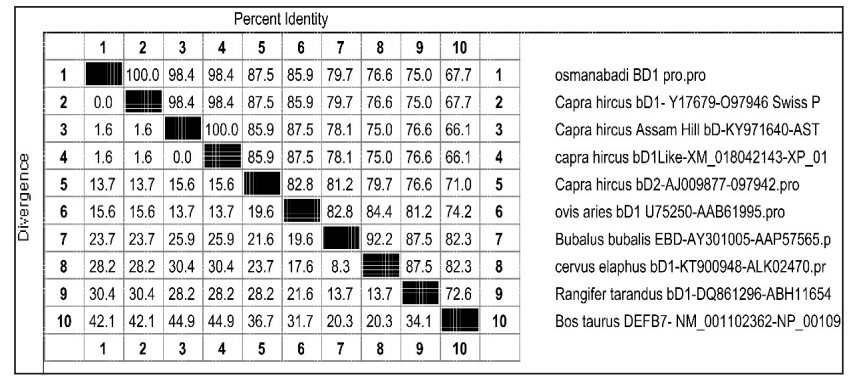

(b)

Fig. 2: Sequence distance of Goat $\beta$-defensin 1 (a) at nucleotide level; (b) at amino acid level

Phylogenetic tree analysis revealed that $\beta$-Defensin- 1 of Osmanabadi goat is closely related to goat, sheep and Reindeer sequences (both at nucleotide and amino acid 
level) (Fig. 3a \& 3b). Structure of the goat $\beta$-Defensin-1 was predicted with Phyre2 (Kelley, et al., 2015) (Fig 4). The structure of goat $\beta$-Defensin- 1 was based on chain A, bovine neutrophil beta-defensin 12 (PDB: 1BNB_A) (Selsted, et al., 1993, Zimmermann, et al., 1995). Phyre2 utilized 35 (55\% of the sequence) residues $99.3 \%$ confidence for building the model of goat $\beta$-Defensin- 1 . Predicted secondary structure of goat $\beta$-Defensin- 1 had disordered region (50\%), alpha helix (48\%), Beta strand $(12 \%)$ and one TM helix (25\%).

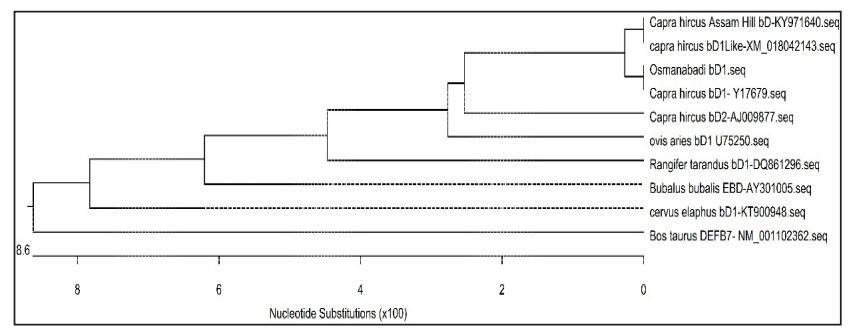

(a)

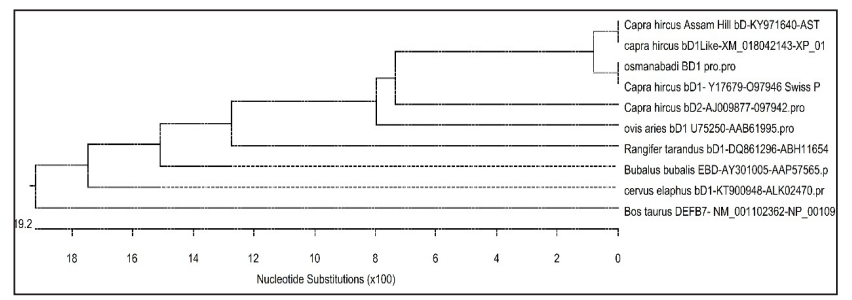

(b)

Fig. 3: Phylogeny of Goat $\beta$-defensin1 (a) at nucleotide level; (b) at amino acid level

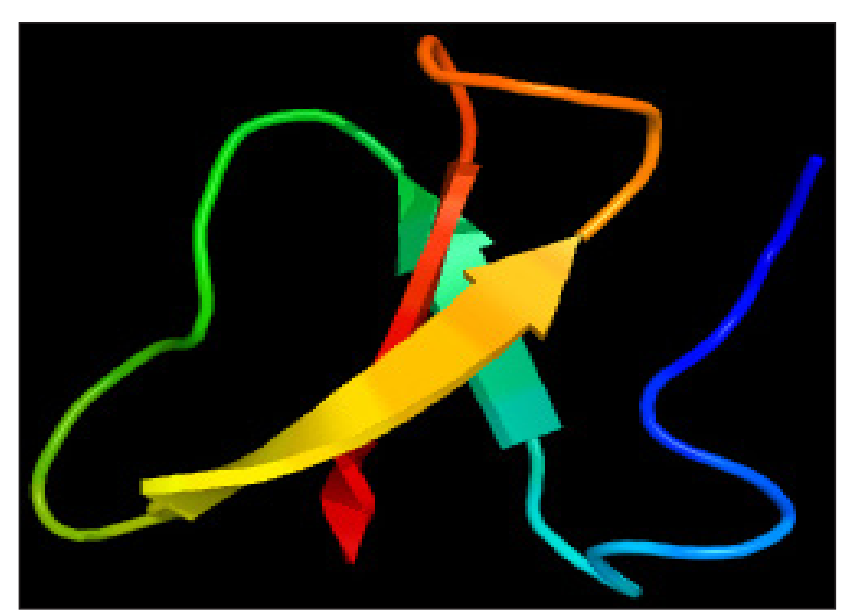

Fig. 4: Predicted structure of Goat $\beta$-defensin- 1 residues 28 to 64: Color rainbow $\mathrm{N}>\mathrm{C}$

Journal of Animal Research: v. 11, n. 1, February 2021

\section{CONCLUSION}

In silico characterization of osmanabad goat $\beta$-Defensin- 1 cDNA and its deduced peptide was carried out in this study. Multiple alignment at nucleotide and amino acid level revealed that Osmanabadi goat $\beta$-Defensin- 1 had high homology with published goat sequences. Phylogenetic analysis revealed that $\beta$-Defensin-1 of Osmanabadi goat, both at nucleotide and amino acid level, is closely related to goat, sheep and Reindeer sequences. Osmanabadi goat $\beta$-Defensin- 1 cDNA sequence from the current study is identical to goat $\beta$-Defensin-1 reported from USA.

\section{ACKNOWLEDGEMENTS}

Authors are thankful to Associate Dean, KNP College of Veterinary Science Shirwal for supporting the research and necessary facilities.

\section{REFERENCES}

Brogden, K.A., Ackermann, M., McCray Jr, P.B. and Tack, B.F. 2003. Antimicrobial peptides in animals and their role in host defences. Int. J. Antimicrob. Agents., 22: 465-478.

Kelley, L.A., Mezulis, S., Yates, C.M., Wass, M.N. and Sternberg, M.J.E. 2015. The Phyre2 web portal for protein modeling, prediction and analysis. Nat. Protoc., 10: 845-858.

Maia, F.S.P., Campelo, J.E.G., Sarmento, J.L.R., Silva, C.S., Marques, J.R.F., Alves, F.A.S., Guimarães, R.C. and Filho, E.S. 2019. Association of polymorphisms of the $\beta$-defensin- 1 gene with nematode and protozoan infection traits in goat. Parasite Immunol., 41: e12613.

Panda, R., Ghorpade, P., Chopade, S., Kodape, A., Palampalle, H. and Dagli, N. 2016. Effect of heat stress on behaviour and physiological parameters of Osmanabadi goats under katcha housing system in Mumbai. J. Livestock Sci., 7: 196-199.

Selsted, M.E., Tang, Y.Q., Morris, W.L., McGuire, P.A., Novotny, M.J., Smith, W., Henschen, A.H. and Cullor, J.S. 1993. Purification, primary structures, and antibacterial activities of beta-defensins, a new family of antimicrobial peptides from bovine neutrophils. J. Biol. Chem., 268: 6641-6648.

Zhao, C., Nguyen, T., Liu, L., Shamova, O., Brogden, K. and Lehrer, R.I. 1999. Differential expression of caprine $\beta$-defensins in digestive and respiratory tissues. Infect. Immun., 67: 6221-6224. 
Zharkova, M.S., Orlov, D.S., Golubeva, O.Y., Chakchir, O.B., Eliseev, I.E., Grinchuk, T.M. and Shamova, O.V. 2019. Application of antimicrobial peptides of the innate immune system in combination with conventional antibiotics-a novel way to combat antibiotic resistance? Front. Cell. Infect. Microbiol., 9: 128.

Zimmermann, G.R., Legault, P., Selsted, M.E. and Pardi,A. 1995. Solution structure of bovine neutrophil beta-defensin-12: the peptide fold of the beta-defensins is identical to that of the classical defensins. Biochemistry., 34: 13663-13671. 